\title{
A Divided Townscape? Ethnic Segregation in Bosnia and Herzegovina - the Mostar Case
}

\author{
Zsolt Bottlik
}

\begin{abstract}
In recent decades, Bosnia-Herzegovina has several times occupied the centre of interest for those watching events in European and global politics. This country is characterized by many specific features, which make it unique not only among the ex-Yugoslavian states, but in Central and Southeast Europe as well. The level of ethnic heterogeneity in this country is among the highest in Europe. The process of transformation after the fall of the communist regime in the 1990s, which was a common feature in the region, was also unique, as it ended in long-lasting bloodshed. After the Dayton accord, Bosnian ethnic communities became more and more isolated and instead of cooperating in building a common homeland they rather reinforced their foreign relationships. Serbs and Croatians turned towards their neighbouring Fatherlands, while the Bosnian Muslims have sought connections with the Islamic world. The ethnic diversity of Bosnia-Herzegovina - with its 51 thousand square kilometres framed by the high mountain chains of the Dinarides, dissected by rivers and polje-basins between them - is very similar to the Yugoslavia from which it seceded in 1992. Like its predecessor, the country only exists owing to the will of powers and not because of natural centripetal forces, as it consists of two entities with hardly any economic or political relations between them, a reality from which arises the question of the maintenance of the state. Ethnic segregation - which was intensified by the events after 1992 - is observable in many towns, creating parallelisms not only in the structure of state administration, but in the usage of symbols, and of urban spaces. This study aims at investigating the roots of these differences and explaining the present, everyday conflicts between the different denominations and cultural groups from the perspective of ethnic geography and based on a case study of the town of Mostar.
\end{abstract}

KEY WORDS Bosnia and Herzegovina, ethnic segregation, urban geography, ethnic geography

The Balkans is an excellent place for the thorough examination of ethnic differences, either by focusing on the population within a clearly delineated area, or on a specific ethnic group. Even before the rise of modern day nationalism in the region in the $19^{\text {th }}$ century, several superpowers with centres outside the Balkans have helped shape the cultural and linguistic character of the area, in addition to that of the political.

In the $20^{\text {th }}$ century, Yugoslavia tried to integrate the many groups with different economic and cultural backgrounds, whose standard of living was also different and remained different despite the ongoing modernizing efforts at the time. Thus, differences in ethnicity were present

Sociální studia / Social Studies 1/2017. Pp. 71-93. ISSN 1214-813X. 
along with the other dividing lines of society. It is in part due to this that the war following the disintegration of Tito's Yugoslavia (except for Slovenia) slowed down the transition to a market economy and other societal changes following the change of regime, yet it has also brought about other, significant, changes.

One unique characteristic of this situation is that Bosnia and Herzegovina is considered a unified entity only because of the foreign policy doctrines of the political superpowers, since it is actually made up of two distinct entities: Republika Srpska and the Federation of Bosnia and Herzegovina, and an area (condominium) governed by both parties, the Brčko District. The economic and political ties between the two parts of the country have recently become stronger, yet several political players have periodically contested the unity of the state.

The background of the country's differences along religious, ethnic, and now even political lines, the background of the conflicts, and the question of what economic, demographic and migratory effects the war of the early 1990s had on the different ethnic groups, have been widely researched. However, it is now timely to examine how those differences that make living together difficult or, at times, impossible are loosening up on a micro level. Do these differences show up and become apparent, if only for the lay observer, on the level of symbols, use of space, and everyday behaviour from the perspective of almost a lifetime after the war? (Juhász 2005)

This article focuses on a geographical approach to the questions at hand. From among the dimensions of this study, the macro-level provides a view of the wider connections, and the factors affecting the evolution of a group consciousness in the In-Between European region are provided by a historical framework. On the mezo-level, we look at the ethnic space structure of the population of Bosnia and Herzegovina, and the changes therein following the war of the 1990s. This is how we approach making our micro-level examination, namely, in terms of city space.

The methods used on the three levels of examination are different. While the macro-level touches upon the theoretical background and the different definitions of the nation, on the mezo-level we use the traditional tools of ethnic geographical analysis to demonstrate the characteristics (ethnic self-definition) of the population through the use of cartographic methods (Jordan 1995; Happel and Werdt 2010; Kocsis and Tátrai 2015). City spaces are investigated from a geographic perspective, and the study concentrates on the long-term changes in cities' functional uses (Simmel 1903; Sýkora 2009; Berki 2014; Kostof 1992) and on the different uses of city spaces as symbols by different ethnicities. The examination of the latter - as an initial step in investigating ethnicities from a geographical perspective was carried out using the "walking as method" (Pierce and Lawhon 2015) approach, which is already accepted in the field of city research, as well as by methods of participant observation.

Within the theoretical framework of this study, the differences between the modern perception of nation and the Western European definitions of nation must be noted. In our region of In-Between Europe (Pándi 1997; Szücs 1985 - which can best be described as a historical collision or buffer zone between the Russian, German and Ottoman Empires, 
characterized by small states after World War I $)^{1}$ - the self-definition of the population is best reflected by the concept of cultural nation (Hobsbawm 1991; Ring 2004). In contrast to the Western European definition of nation state, the people living here define themselves based more on the common experiences of a cultural community consciousness. The development of the feeling of a cultural nation is a process in which a community consciousness is formed by common lingual-cultural-(religious) aspects, as created by the medieval state framework. This community consciousness usually goes through the status of proto-nation, before it becomes a modern "imagined community" (Anderson 1983). During this process, the "political nation" or natio Croatica, based on sacred loyalty, and involving only certain social groups (together with other, different groups in society), becomes the community of the inhabitants of the modern state (Steindorff 1997). This process is characteristically seen in the group of Muslims speaking the Southern Slavic language, who, while defining themselves as Bosnians, developed their own secular group consciousness. This - similarly to most of the East-Central-European nations, where the same process took place earlier - also meant the formation of their modern ethnic consciousness and identity.

The territories of Bosnia and Herzegovina of today were situated in a political and cultural buffer zone even in the early Middle Ages. The linguistic situation was greatly influenced by the infiltration of the Slavs in the $6^{\text {th }}$ and $7^{\text {th }}$ centuries, which did not mean linguistic unity in a modern sense, but it did provide some sort of common framework.

Following the East-West Schism of 1054, the region became a border territory between the influence of the Western and Eastern bulwarks of the Christianity, Rome and Byzantium. However, neither religious group managed to gain ground permanently. In the $13^{\text {th }}$ century, a third Christian school started to become stronger in the region, from which - simultaneously with the secular powers - the Bosnian (Bogumil) church (Crkva Bosanska) was later created, a church that became predominant in the area (Džaja 1984; Malcolm 1994). The presence and the supported activities of the Franciscan Order also played a significant role in the weakening of the other two main churches.

As a result of the Ottoman occupation of the region in the $15^{\text {th }}$ century, and due to the significant migration as a result of this, the above-described religious situation gradually changed from the middle of the $16^{\text {th }}$ century. The number of Roman Catholics decreased greatly due to the out-migration of the followers of the Western church to the north, and the conversion of a part of the population to Islam. In addition, the in-migration of followers of the Orthodox and Islamic faiths, as well as the significant number of conversions to Islam, led to a shift in religious representation (Balić 1991; Lopasić 2001).

About the geographical nature of the Islamisation process, it can be said that the number of Muslim inhabitants rose mainly on the lower-lying plain regions of the West Balkans, the river valleys, and areas capable of agricultural farming, along with the areas around the more commercially and strategically prominent roads (Džaja 1993). Another geographical aspect of the rise in the population of Muslim-inhabited areas is that the Muslims lived in

The term "In-Between Europe" contains numerous sub-regions with different features, of which East-Central Europe is only one component, in addition to the Balkans, the Baltic States etc. 
cities and areas around cities in much higher numbers than the Christians (Ibrahimi 2009; Demeter 2014).

The city of Mostar lies in such a geographical environment, in the expanding valley of the north-south bound Neretva, in the central region of Herzegovina (Picture 1). It must be noted here that the term "Bosnia and Herzegovina" refers to two historical and geographical regions. The larger, northern part is Bosnia, which received its name from the Bosna River, while the southern region's historical name is Herzegovina. This latter name is derived from the title of "Prince" of Stjepan Vukčić Kosača, who united two medieval Southern Slavic territories, Zehumlje (Hum) and Travunje (Malcolm 1994). The settlements, which had central functions at the time, took on the Eastern characteristics that we can observe today in the first dynamic decades of the Ottoman period. The townscape characteristic of the city up until the $19^{\text {th }}$ century took shape in the $15^{\text {th }}$ century, even though the city had been founded shortly before the Ottoman conquest.

The $16^{\text {th }}$ century was Mostar's first, if not only, real golden era, when it grew into Herzegovina's largest city, making it the centre. This was mostly due to the expansion of the Ottoman Empire, as the city's growth was based in large part on the industries serving the militia stationed here (commerce and different trades), and its strategic location. The population - as in other cities of the Empire - was mainly Muslim; however, the Christians, already living in the area, lived along with the Muslims, who had been living in the areas around the city previously.

Picture 1: The Old Bridge in the evening light from the minaret of the Koski Mehmed Pasha mosque

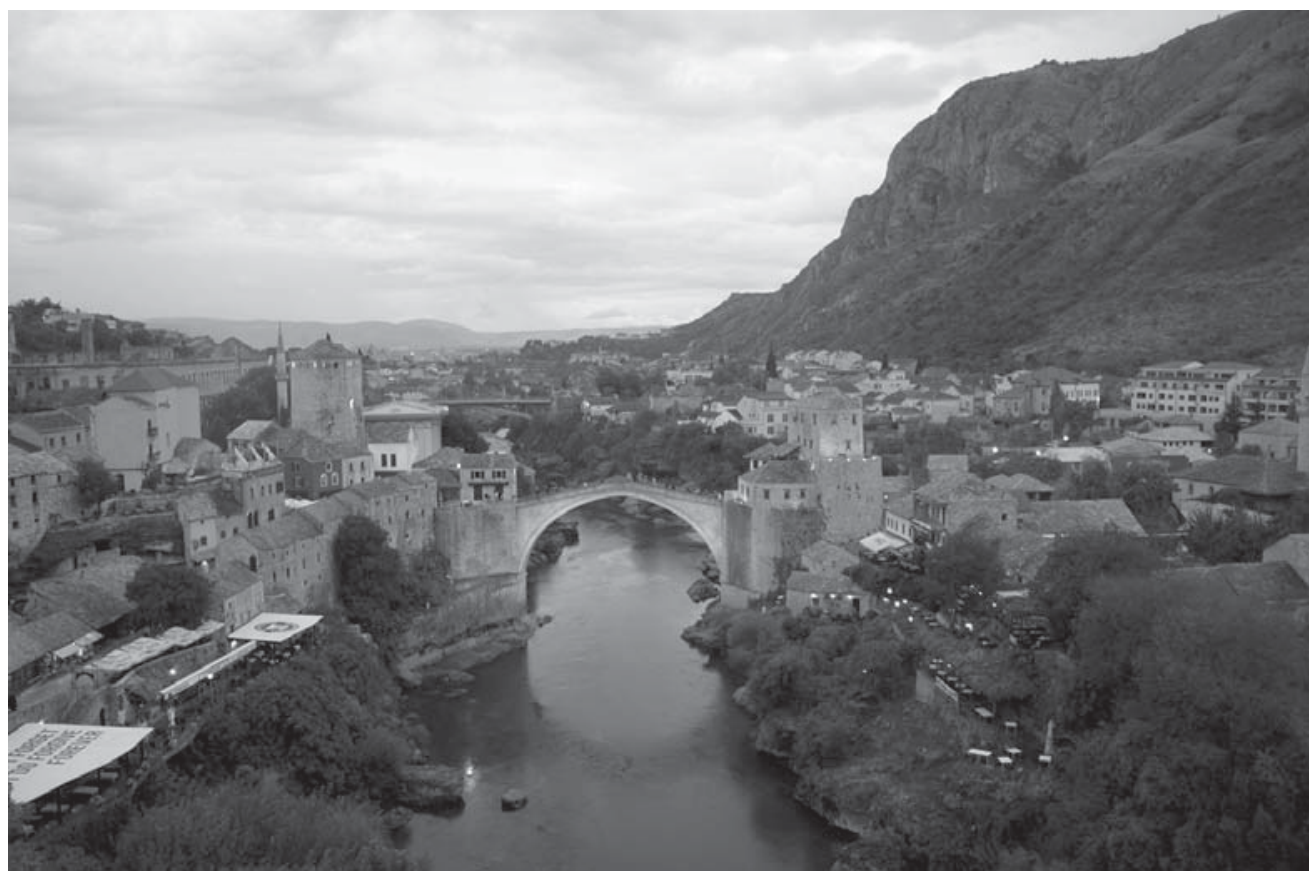

Source: Author 
In Mostar, due to its dynamic growth, the traditional structure of the Ottoman cities developed (Asbóth 1890; Demeter 2016). The face of the city was formed by the large constructions funded by the Maecenas of the time. Two large structural, functional units can be observed: the commercial centre, and the residential centre surrounding it (Picture 2). This layout can be observed to this day. In the commercial centre surrounding the Old Bridge, built in 1567, on the left of the Neretva you could see the stalls of craftsmen, while on the right side small retail shops were the foremost trade of the inhabitants. Narrow streets full of small shops, buildings used for storage (small warehouses), baths and caravan lodgings characterized the hustle and bustle of the $16-17^{\text {th }}$ century.

The momentum of the territorial expansionist policies of the Ottoman Empire stopped in the $17^{\text {th }}$ century. The Turks' expulsion from central Hungary also increased the strategic importance of Mostar. The Muslim administration and population fleeing from the emptied Hungarian territories found a home here, in the regions which were also allotted the role of guarding the border (we mainly have to mention the surrounding areas of Bihać, and the fortresses on the banks of the Sava and the Una Rivers). With this, the ratio of Muslims only increased, having made up a sizeable portion of the cities' populations even before this migration. The leaders of the city, the Ottoman administrative powers, and influential economic groups all came from this Muslim community. (Malcolm 1994)

One of the foundations of the social organizing factors in the Ottoman Empire was the strengthening of the position of groups of the Muslim faith. As a juxtaposition to this, the Catholics living mostly in the countryside, or near the cities, but mostly in their hinterlands, tried to fulfil the "nationalistic" framework of the time by strengthening their religious communities. The Orthodox population living in the same areas did this by identifying themselves as separate from the Greek primate-led Orthodox millet. The orientation of the heterogeneous Muslims, differing from these two groups not only socially but often linguistically, too, was very different. This fact fundamentally separated them from the other two groups (Catholics and Orthodox), who were different from them socially and in standard of living (Džaja 1984).

While in the $19^{\text {th }}$ century the Croatian and Serbian nationalist movements had already expounded serious political aims, there was no national unity in the modern sense among the Muslims of the Balkans. This only happened simultaneously with the expulsion of the Ottoman Empire from the Balkans. The three stages of the ethnic awakening and selfdefining of the southern Slavic-speaking Bosnian Muslims was shaped by the political changes happening during the hundred-year period from 1878 all the way to the 1970 s.

1) The Muslims regarded the military occupation of Bosnia by the Austro-Hungarian Empire as temporary, and they tried to stabilize their positions not so much on an ethnic basis as on their privileges. As many of them chose to migrate from the region, due to their dilapidated societal structure and a lack of national literature (Halilović 1999), the progression of their existing common group identity away from a proto-nation did not take place. And the leading powers - afraid of the rise in power of the Empire's Slavic peoples - tried to emphasize their identity linked to their geographical ties, their "Bosnian" nature (and by this aimed at supporting the building of a nation), as opposed to an Ottoman identity. 
Picture 2: The organic unity of the old economic centre is clearly visible from the hills towering over the city

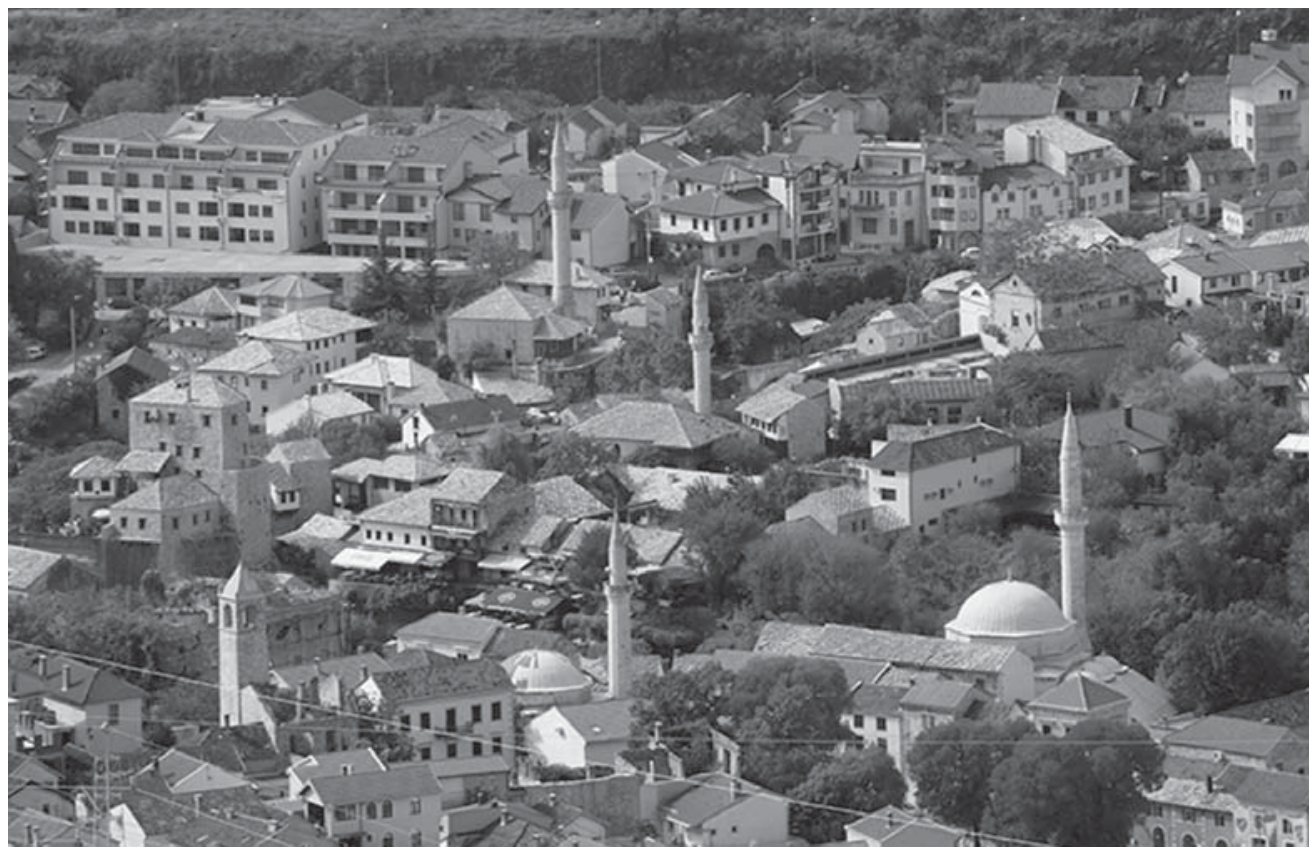

Source: Author

In addition to the relics of the Ottoman Empire, the period of the Austro-Hungarian Empire left its mark on the image of the city with several architectural elements (Moravanszky 1998). Apart from the fact that Eastern European traditions in architecture were evident in the buildings and quarters built at the time, this was also the period when the spaces for work and living - functionally and physically separated areas in Ottoman times - started to blend together. The city began to expand towards the west and the north, and the centre of town, previously situated around the Old Bridge (Stari Most), gradually lost importance; that is, the functional usage of space in the city changed because of a new political infrastructure and due to economic necessity as well, while the Muslim layer of society also became stranded on the periphery from its previously central geographical and social position (Loza et al. 2004).

2) In 1918, the Kingdom of Serbs, Croats and Slovenes (from 1929 on, known as Yugoslavia) was formed, which included the territories of Bosnia and Herzegovina, and which basically supported Serbian interests in its centralist structure. From 1929, government authorities tried to weaken the Muslims, who did not possess a well-defined ethnic area, by rearranging the administrative areas (creating the so-called banovinas), dividing the areas populated by them into different administrative regions. This period was characterized by the continuous search by Muslim political leaders to discover where they belonged. They either swayed towards Serb politics, or Croatian efforts of autonomy, despite the fact that the goal of the Serb-Croat political wars was actually to split up Bosnia and to melt 
the Muslims in the area into the melting pot, or, at least, to push them to the peripheries of the economy and politics.

This period was one of quiet stagnation in the life of the city that was still considered the capital of Herzegovina. This was mainly due to the fact that, as a result of the administrative restructuring, the city occupied a much less central position as before, and was also at the periphery in terms of state investments, which generally were not allocated here. However, this may also have been due to the fact that the greater metropolitan area contained a large number of non-Serbian inhabitants. Thus, the Interwar era was not characterized by significant construction activities.

3) In socialist, Titoist Yugoslavia, Serbian nationalist aspirations were replaced by the ideology of "brotherhood and unity" of a proletarian, internationalist nature. Paradoxically, the goal was to acknowledge the Slavic-speaking Muslims as an independent nation and to lift them up to the ranks of other southern-Slavic peoples (those that had a status of a Republic) (Voss 2006). In the 1960s, Yugoslavia stood at the forefront of the Non-Aligned Movement (having been expelled from the socialist bloc), and as a result established good relationships with many Muslim countries. These developments, in contrast to the previous one hundred years, strengthened the Bosnian Muslims both economically and in their sense of identity from the 1960s onwards. Before this, the Bosnian Muslims had defined themselves as primarily a religious community. The changes of the 1960s helped to shift their identity towards the secular modern nation state and it was also when the term "Bosnian" spread to all of the different groups in the region.

Thus, Mostar was thriving in this period. The city had once again become an economically prospering centre of Herzegovina with a significant Muslim (Bosnian) population. Most of the city's western parts (and its southern forefront) were expanding rapidly, primarily due to the labour needs of a developing economy (for example in aluminium metallurgy and the construction of a water power plant and tobacco factory), and as a result of the natural geographical advantages of the city. This is when the new centre of the city was permanently located on the right side of the Neretva, and new parts of the city were born, with their multistorey high-rise buildings, and when the mostly Croatian-populated, surrounding settlements also united with the city (e.g. Balinovac, Cim).

However, the old town centre remained largely intact, and has been a significant tourist attraction ever since tourism became a dynamic industry in the Yugoslavia of the 1970s.

The basis of the ethnic differences between different groups of the country's population was defined by the people's social situations - be it due to cultural differences, or, as in the Ottoman Empire, religious differences. These differences, as we have seen, have always had significant effects throughout history, influencing even the social structure. Nationalist movements have tried to satisfy the need for national mass feelings on the basis of these differences. The modern identity of the Balkan nations usually goes back to pre-modern experiences, traditions, and the old state frameworks, and their identity is further strengthened by linguistic and social differences (Steindorff 1998). As opposed to this, the fact that Bosnians stood culturally (religiously) apart, and they had a separate, regional identity, helped in the strengthening of their own modern, secular self-identity. Despite the fact that Tito's Yugoslavia tried to manage the problems arising from national differences, it could not 
completely dampen the fires arising from these differences of identity. Thus, in the wake of political changes in In-Between Europe and in parallel the change of regime, the complete disintegration of the Yugoslav ethnic mosaic started with a bloody war.

Figure 1: Ethnic composition of the population in the opštinas of Bosnia and Hercegovina (1991-2013)

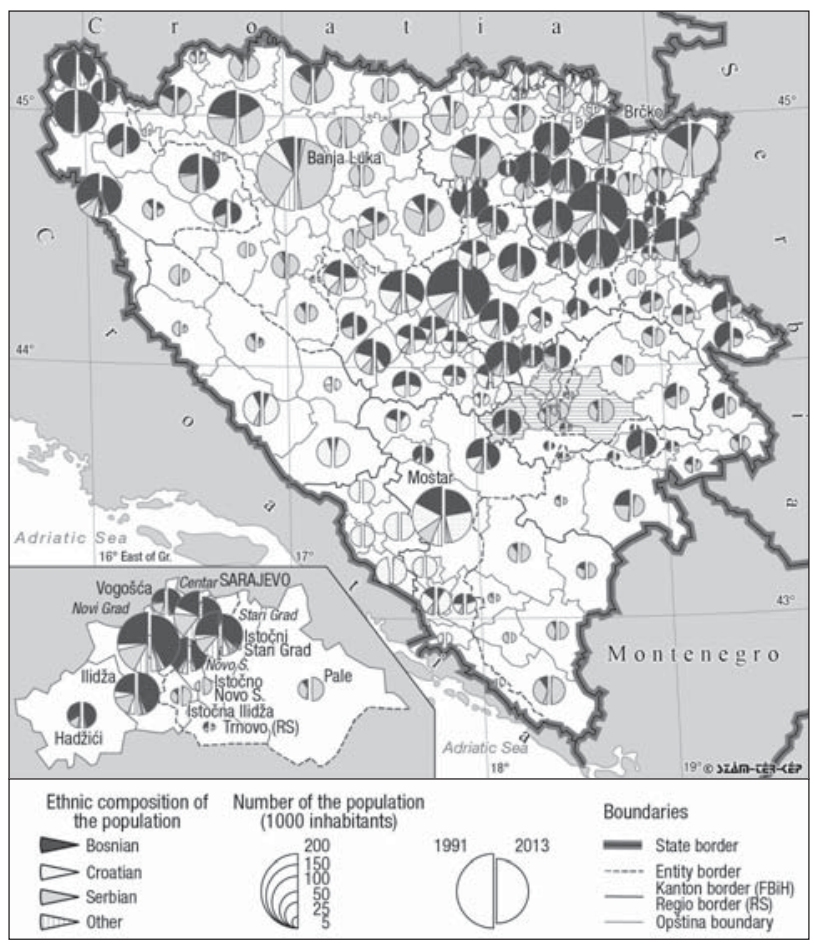

Source: Census Data 2013, Statistical Office of BiH

Ethnic segregation in Mostar is best understood in the larger framework of correlations that are visible in the restructuring of the country's spatial structure, largely due to the effects of the war. The current spatial structure, and the demographic consequences of the bloody war that broke out in the early 1990s, can be demonstrated by the data referring to nationalities as seen in the last complex Yugoslavian census of 1991 and the first complex Bosnian and Herzegovinian census of 2013 (Figures 1 and 2).

It can be also be concluded from the figures that the composition of the population is to this day influenced by the duality of the Christian religious situation of the early Middle Ages, coupled by the appearance and large-scale spread of Islam. However, the war of the 1990s has visibly altered the ethnic structure that developed in Ottoman times, and almost everywhere altered the ethnic ratios, as well.

Loss of human life has to be mentioned as one of the first and foremost effects of the war. One part of the population died during battle, but many lost their lives during episodes of ethnic cleansing (about 100 thousand people altogether) (Büschenfeld 2000). The number of 
injured is also quite high, people who have lost their ability to work either wholly or partially. We have to mention increased internal migration and emigration (partly forced) as part of the effects of the war, as this affected almost all of the country's population. The drastic drop in population numbers is largely due to the loss of those who have gone abroad, but the changes in the ethnic spatial structure also show the importance of internal migration. The change in the political situation is well reflected in the unique and new political structure of the country, as part of which two entities (Republika Srpska and the Federation of Bosnia and Herzegovina) and the Brčko District were formed (Steindorff 2001).

Figure 2: Majority and Minority groups of opštinas in Bosnia and Hercegovina (1991-2013)

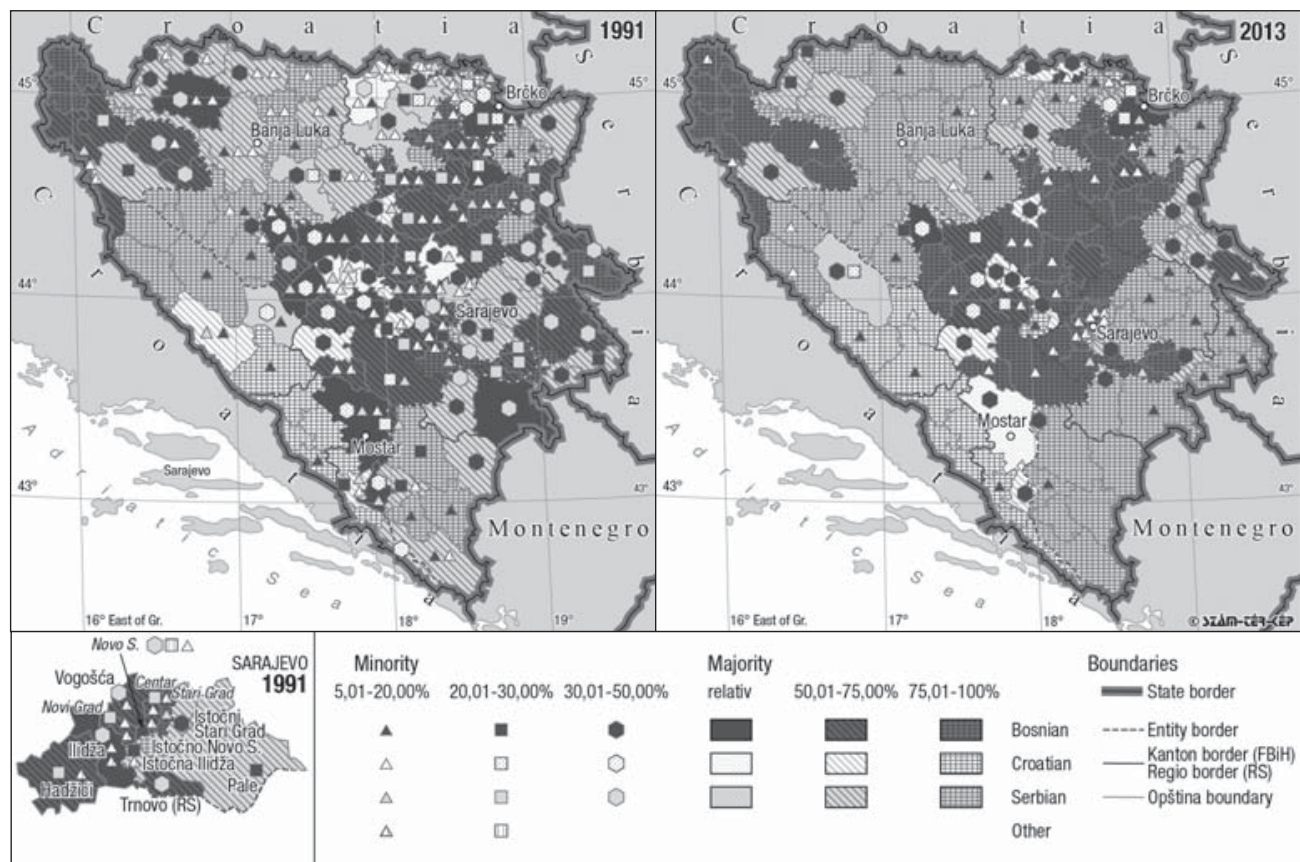

Source: Census Data 2013, Statistical Office of BiH

Regarding the territorial nature of these changes, it can be said that the decrease in population is most apparent in the opštinas of the front line, in the eastern Bosnian territories and in the areas with a large heterogeneity. This is mostly due to the fact that everybody struggled to get to their own group's territory, while fleeing the battles and genocide. This is how the number of Serbs decreased in the Federation of Bosnia and Herzegovina; how the number of Muslims (Bosnians) fell in the eastern-Bosnian region belonging to the Serbian group; and how the number of Croats decreased in the north. These changes resulted in the high concentration of ethnic groups in the areas where they already formed a majority. The census category of "Other" in 1991 mostly meant those who categorized themselves as "Yugoslavian", in the sense of belonging to the Yugoslavia of Tito, a state above the nations. By 2013 this category showed the number of people who didn't want, or 
refused, to give an answer in the census. As a general phenomenon, their presence is highest in the cities and in the most heterogeneous regions. Despite these trends, the country is still one of Europe's most heterogeneous nations (Figures 2 and 3).

Figure 3: The number of the opštinas by the majority ethnic group and distribution of the population by ethnic groups in the entities and in the country in Bosnia and Hercegovina (1991-2013)

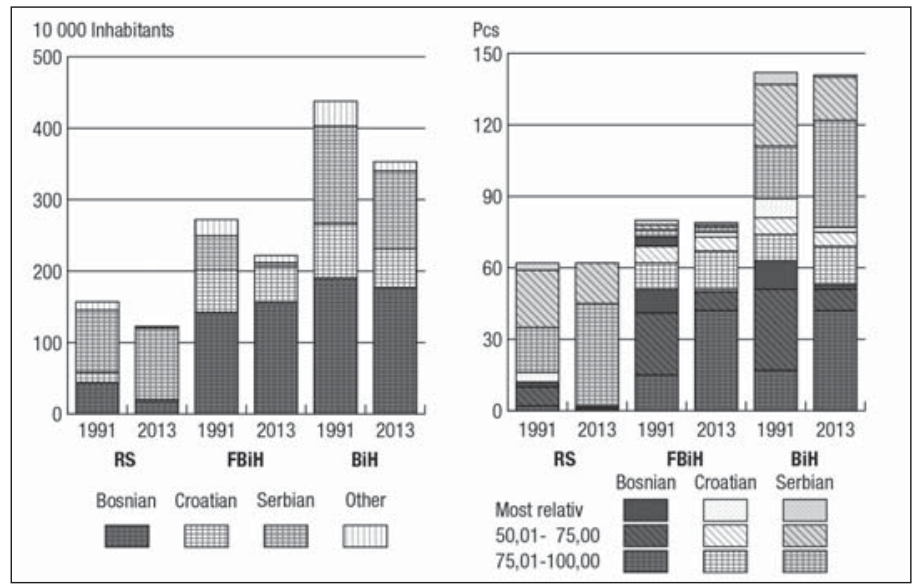

Source: Census Data 2013, Statistical Office of BiH

Note: $\mathrm{RS}=$ Republika Srpska; $\mathrm{FBiH}=$ Federation of Bosnia and Hercegovina; $\mathrm{BiH}=$ Bosnia and Hercegovina

Upon the declaration of the independence of Bosnia in 1992 the Serbs, supported by the Yugoslav Army, gained control over a substantial part of the country. At this time, the Croats and the Muslims were still fighting together against the Serbs. As a result, the Bosnian Croatian leadership, having no faith in the independence of the country, declared the Croatian Republic of Herzeg-Bosnia in the summer of the same year. The war thus became tripartite. In the autumn the Croats blockaded Mostar, which they intended to make the capital of their breakaway state because of its geographic and strategic significance.

The city was split in two during the hostilities, and the Bosnians living in the western areas controlled by the Croats were expelled. The front line, which stabilized along the high street on the right side of the river, split the city in two. First, religious buildings with symbolic significance (churches, monasteries and convents) and educational institutions were systematically destroyed through a series of artillery attacks. Within that, the Old Bridge, an emblematic monument of the city, was also demolished. Bridges are usually of strategic importance in armed conflicts. However, in this case, the symbolic meaning of the bridge for Muslims was also a cause for the Croats to blow it up. Later, the urbicide was completed by the annihilation of residential and commercial buildings and the infrastructure (Luchetta 2009). By the time the Croatian Bosnian resistance was eliminated under American pressure and the Bosnian Croatian federation was created in 1994, Mostar became the most severely bombed and destroyed city of the Yugoslav wars of the 1990s. 
If today we look down from the hills that surround Mostar, thankfully the marks left by the war can hardly be spotted in the city, which was rebuilt mostly with Western support (as in the famous case of the historical bridge). However, the war's abovementioned effects are noticeable on a micro level even just by taking a walk in the settlements that once comprised the front line, including Mostar - with the addition that its losses suffered during the war do not shape the urban landscape substantially any longer. Although the walls of several formerly significant buildings (that often have a symbolic meaning for one of the communities) are still towering towards the sky as a sort of memento, the cityscape is mostly characterized by renovated communal and residential buildings, and neat urban spaces and parks (Yarwood 1999).

At the same time, the population of multi-ethnic Bosnian cities has greatly homogenized due to the understandable air of distrust that arose in the wake of the war. Formerly, the ethnic composition of the city was characterized by national trends. The relative majority were Muslim Bosnians, recognized as an ethnic group in 1971. Substantial groups of Croats and Serbs also used to live in the city. As a result of the war, the Serb population has decreased drastically - today it counts only 3000 heads, even though it used to be a much bigger community. Due to the great number of war casualties and a high rate of emigration among the Bosnians, the relative majority of the population today is comprised by Croats, according to recent data. And with the disappearance from the census of the former, ethnically neutral category of "Yugoslav", the number of people putting themselves into other categories has also declined significantly (Figure 4).

Figure 4: Population changes by the ethnic groups in Mostar (1961-2013)

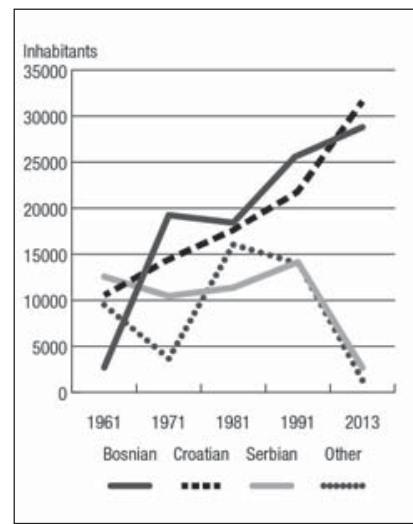

Source: Census Data 2013, Statistical Office of BiH

Another consequence of the war is that - after the emigration of the great majority of the Serbs - the two largest communities have been living in a highly segregated way along the main road dividing the town, the former front line between warring parties (nowadays simply called Bulvar) - technically in two separate Mostars. After the war, the city received a special legal status ("unified city"), which was given solely to Mostar in the country (Niemann and Reuber 2015). The delicately balanced power structure supports the Bosnian community, even though it is smaller in numbers, as they have a smaller electorate and are entitled to have the same number of representatives in the city council (Grodach 2002). Since 
2008, they have not managed to elect a mayor, as there is no agreement between the highly ethnicized parties.

Regarding ethnic composition, the city could be considered multi-ethnic; however, the fault line between the two largest groups is rather deep, which is perceivable even to the superficial observer. The effects of the historical events outlined above are also visible in the structure of the city. The city has two centres and several sub-centres, as well as symbolic buildings, and there has been a fairly strong ethnic factor in their establishment and use, as well. The following statements can be followed in Figure 5.

Figure 5: Functional zones and major objects of central Mostar

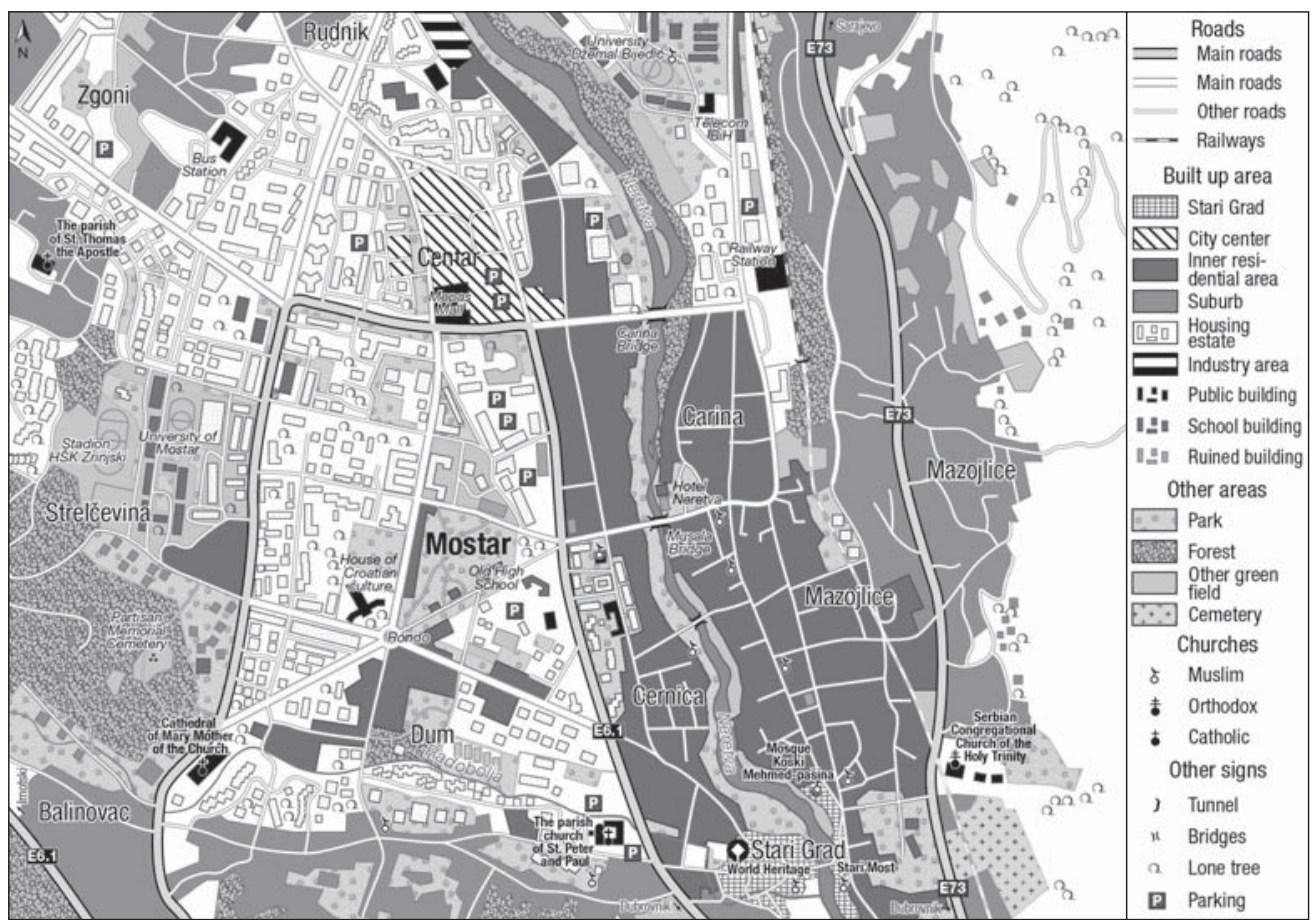

Source: Author

The historical city centre, which remained nearly intact, is located around the Old Bridge, after which the city was named (Picture 2). The function of the majority of the buildings standing here has hardly changed for centuries. Handicraft and retail businesses still dominate the space. However, the goldsmiths and leather handicraft workshops have been mostly replaced by shops selling souvenirs, oriental - often Chinese - jewellery or massproduced kitsch items. Many former workshops have been turned into cafes, teahouses or restaurants that add further colour to the district. The mosques in the area (also) function as tourist sites. The mass tourism received by Mostar is attracted mainly by this part of the city, with its compact and unified oriental atmosphere, which makes it especially interesting for 
Western Europeans. It is no coincidence that most travel agencies feature the buildings of this district in their advertising and brochures.

In the centre of the area is the bridge, the symbolic meaning of which shows differing attitudes. According to the Western stance (examining the situation from the outside), it connects the different cultures (West-East), nations (Muslim Bosnians, Orthodox Serbs, Catholic Croatians). In this respect, the success of rebuilding means the resuscitation of these principles, too. For the locals, however, the bridge has carried and carries to this day a different meaning. The Croats saw, and see to this day, in it the Muslim past, the Muslim heritage. For the Bosnians, on the other hand, it not only carries a special symbolic meaning, but it is also an important meeting point, the site of social contact (Gentzik 2008).

Although in terms of visuals the district evokes historical (Ottoman) times, in terms of function and space usage, the whole area serves the sole purpose of tourism. And tourismrelated activities define the life of this district that is inhabited almost exclusively by Bosnians Muslims.

It is generally true of the settlements of the Balkans with a historical significance that the old centre has lost some of its importance, and the centre of the activities dictated by a changed lifestyle have moved to a different - or even new - district. This is mostly a $20^{\text {th }}$ century phenomenon in the cities and towns of the Balkans (Köszegi 2015). In many places the old centre not only became empty (Bitola), but due to a lack of inhabitants it also eroded physically (Novi Pazar, Prilep) or was completely destroyed (Plovdiv, Sofia, Shumen), and it is often only one monumental building, normally the mosque, that is reminiscent of the central functions of the past. For the most part, this is a consequence of social and political changes - the emigration of former inhabitants, or their social marginalization.

Due to the recognition of Bosnians as a separate ethnic group in Bosnia, and the considerable improvement of their general situation in the 1970s, cities inhabited by them tend to have experienced a change in function, rather than suffering physical erosion (Balić 1996). Therefore, in the case of Mostar, the bridge and the surrounding area are the most prominent elements of Muslim remembrance politics. According to our observations, as a consequence of the opportunities offered by tourism and the physical display of identity, Bosnian cities with a substantial Bosnian majority take good care of the symbols of their cultural belonging (buildings, and even certain clearly distinguishable districts); thus, their presence is reflected in the well-maintained built environment as well.

During the times of the Monarchy, north of the historical old city, an enclosed area with a few apartment blocks was created, with several communal buildings and parks of various sizes. These became Muslim cemeteries during the 1992-1995 war, and still function as such, contributing unusual and even strange spaces to the urban landscape (Picture 3). Three road bridges were built over the Neretva during the Monarchy (Musali [1882], Lučki [1913], Carinski most [1918]), which enabled the city to further expand on the other side of the river, starting from the right riverbank abutment of the Old Bridge. The Neretva Hotel, built at the Musala (Tito) Bridge, is a most beautiful example of this era, demonstrating the $19-20^{\text {th }}$ century beginnings of the tourism of the upper class and the emergence/creation of new types of urban spaces (Picture 4). The Carinski contributes to the functions of 
Picture 3: The „Mostar Battalion” street, reminiscent of the „Tito Period”, leads from the Tito bridge to another sub-centre place, the Musala (On the right is the renovated old Turkish bath, while on the left side the blackened walls of the Neretva hotel are reminiscent of the war)

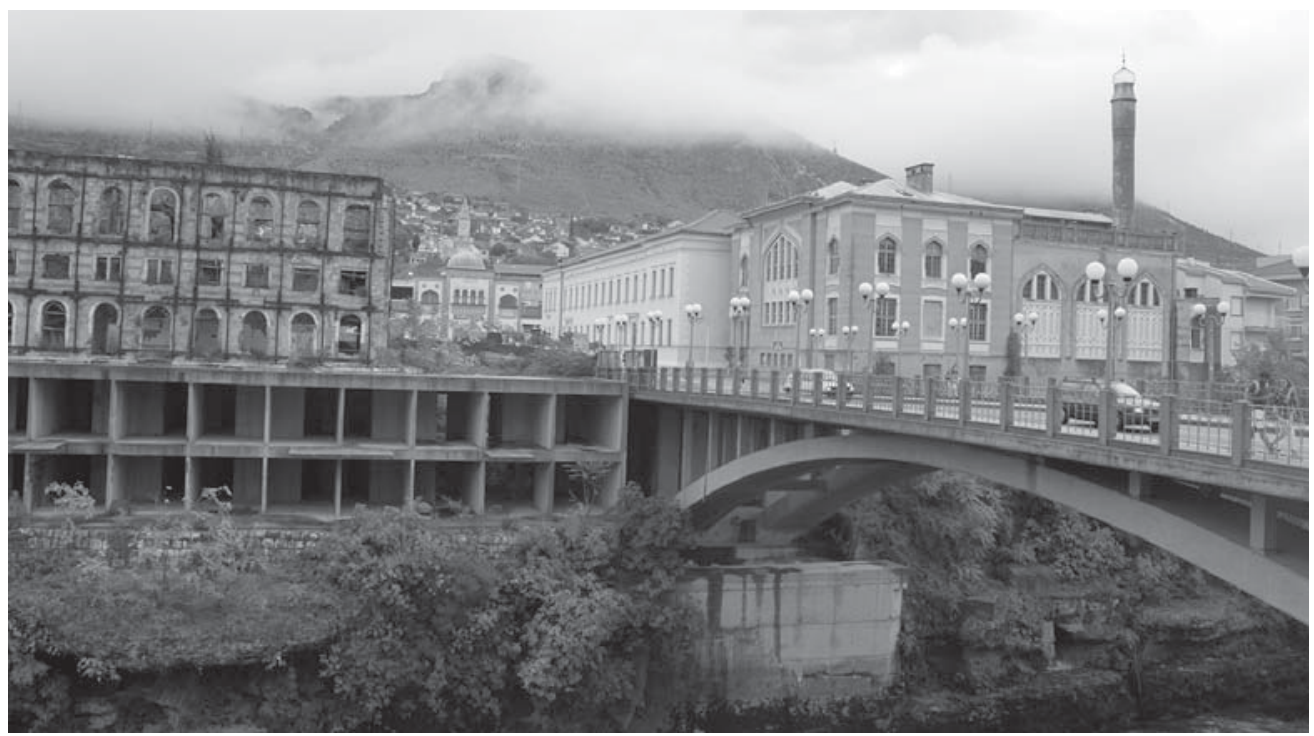

Source: Author

Picture 4: Some of the parks in the Muslim part of town are now cemeteries or memorials (This unfortunately is not a unique feature in the townscape in Muslim-dominated Bosnia and Herzegovina)

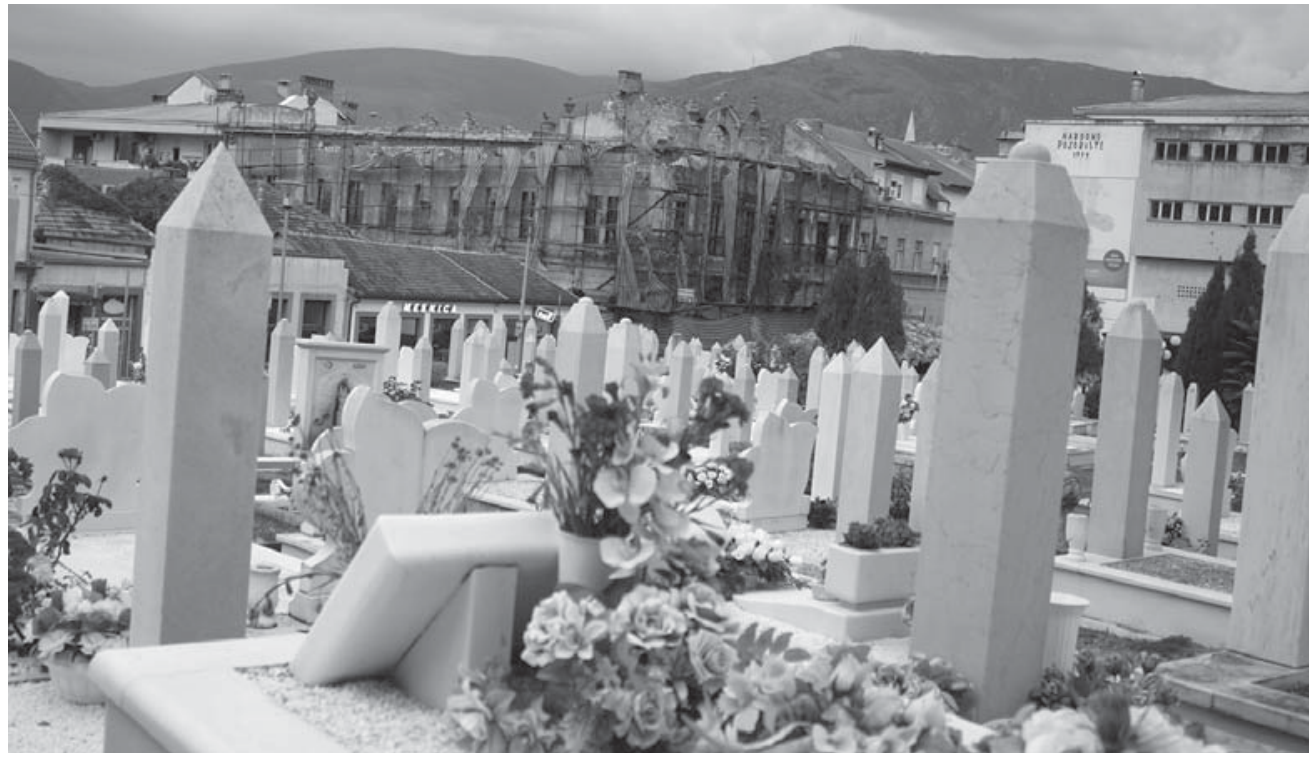

Source: Author 
the station area (built at the end of the $19^{\text {th }}$ century) and its wider surroundings. The spaces that emerged at this time still have central functions and are sub-centres.

The general feelings in society about the period between 1878 and 1918 were mainly positive, although the leaders of the Monarchy aimed to cause a split within the country's population due to the overbearing numbers of Slavic people in the Monarchy, which resulted and showed itself in the strengthening of the self-consciousness of the Slavic speaking Muslims (AmziErdoğdular 2013). As regards the spread and intensifying presence of Viennese politics in the region, the Croatians looked upon it mainly with distrust, and the Serbs with outright animosity. At present, neither ethnic group looks back with nostalgia at this historical period, despite the fairly successful modernization process and the balance that managed to be kept between the different ethnic groups (Okey 2007; Sugar 1964). It is possibly for this reason that, in a city which since has come to have a larger number of Croats, the majority of buildings built in this historical period have not been rebuilt to this day (Fónagy 2014).

In Mostar, the modern centre of the city is located on the right side of the Neretva River, in the western part of the city. This area is made up mainly of prefabricated residential buildings, which usually shape Yugoslav urban landscapes. This district and its use as a modern centre emerged gradually after World War II. Although its functionality is not nearly as complex as in Western or even Central European cities, its central building has been the "mall" (Mepas Mall [Picture 5]) since its opening in 2012, and the rows of shops in nearby streets, the pedestrian street sections, the bigger parking lots, the catering units, and the wide roads make it comparable to other urban centres of the globalized world.

Picture 5: The new centre developed in the 1970's, with a focus on the Mepas Mall and the surrounding prefabricated housing estates

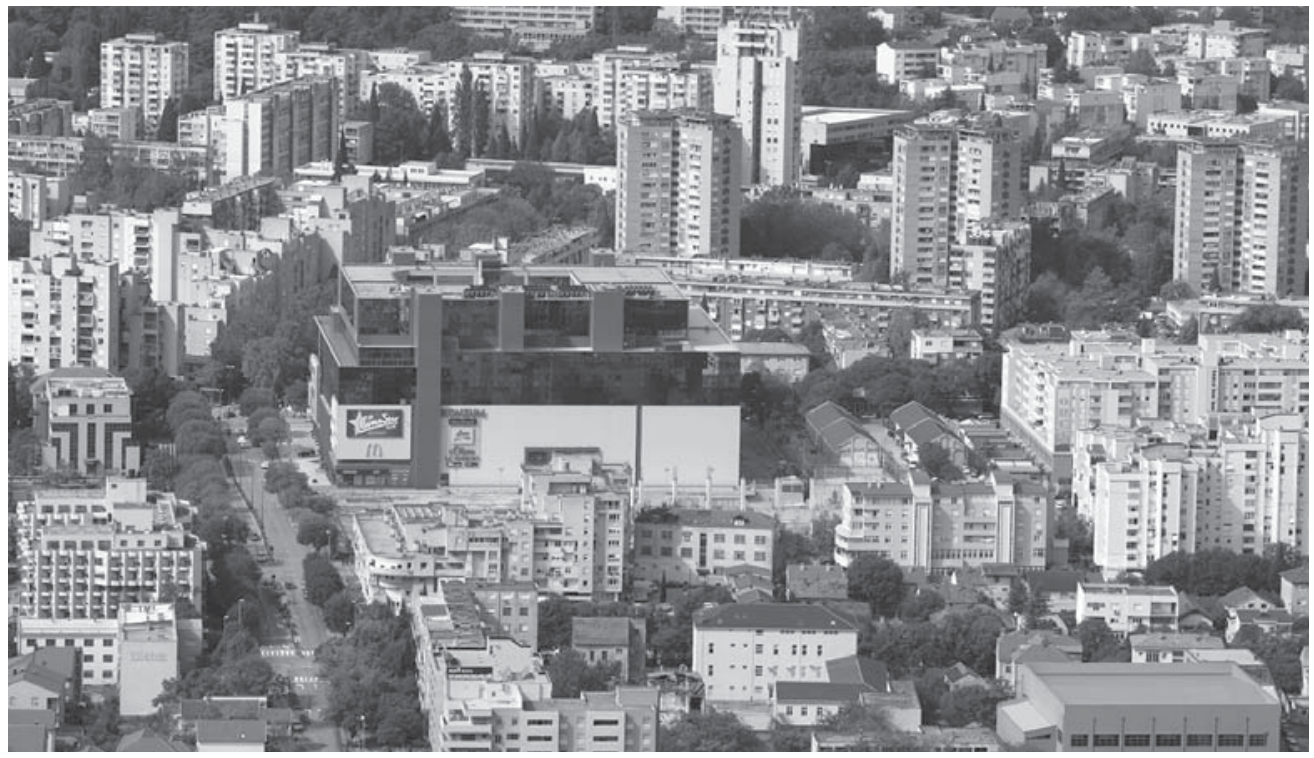

Source: Author 
At the same time, in the areas surrounding the centre, especially at its western edges, spaces are dominated by tall blocks of flats of the socialist era. It is these blocks of flats, and catering units, that fill the formerly empty spaces that lie mainly between the city and the surrounding settlements to the west (predominantly inhabited by Croats). Wide roads, vistas, and parks between the blocks make these spaces liveable. Contrary to the times of the Monarchy, the Muslims look back at the Yugoslav years after World War II happily, because of Tito's supportive policies towards them, as mentioned before (Juhász 2005). Perhaps this is why you can still walk on a street named after Tito in the district inhabited by them.

The city is nearly fully encircled by the area of the "suburban", so-called outer residential ring. On the eastern side, with the north-south oriented E73 international road as its axis, it also contains some of the hillside, while on the western side of the city, smaller areas (Rudnik to the north, Bjeli Breg to the west, and Ballinovác to the south) constitute a functional connection to the administratively separate settlements of Cim and Ilići (Figure 5).

The war of the 1990s has carved deep gaps between the historical cultural and ethnic communities, which is reflected in the symbolism of today's urban spaces and people's use of these spaces as well. Not even the official policies of the socialist era were able to eliminate ethnic identity as the basis for community, despite such elimination being a declared goal.

In the ethnically divided city, when discussing the symbolism of the usage of space by various ethnic groups, one must mention the main road branching from E73 that runs over the Lučki Bridge to the right side of the river, touching on the centre as well, then leaving the city to the west, touching on the nearby town of Ilići, inhabited by Croats. The section of this road neutrally and simply named Bulvar - considering the symbolism of Mostar street names - constituted the front line of the war during the Bosnian-Croatian hostilities (Picture 6). The wide road built during the Monarchy arrives in the western district of the city from the south, and after passing first the historical city centre, and then a series of areas and buildings built in the $19^{\text {th }}$ century that had symbolic significance for the ethnic groups even in the $20^{\text {th }}$ century, it finally reaches the modern centre established in the socialist era.

As the various ethnic groups define their identities predominantly on religious grounds, sacral places have always had special importance to them, and the names of public spaces also have an added meaning. No wonder then that these places were primary targets during combat, and that these were also the first people wanted to rebuild after peace was established, demonstrating the presence of the ethnic group.

First, the primary centre for Croatian identity (largely determined by the Catholic faith during the Ottoman period [Molnár 2000]) is the Franciscan church and its conjoint monastery, which is immediately visible when arriving from the south along the Bulvar. The church was bombed during the war, and then the replacement church building, a reinforced concrete block, was built at record speed. Next to it there is a church tower of a slightly unusual height, 107 meters, which (also) functions as a lookout, which is visible from nearly everywhere in the city, just like the enormous cross on top of Mount Hum overlooking the district from the south, built for the $2000^{\text {th }}$ anniversary of Christianity. Street names also carry special symbolism: the Street of the Franciscans, and the Father Ambre Miletić and Father Milčevića streets demonstrate both the former and present significance of the Franciscans and of the ownership of territory (Picture 7). 
Picture 6: One of the main thoroughfares of the western part of the city, the former front line, the Boulevard (In the background the cross on the Hum-hill, and the Franciscan church spire mark the symbols of space conquered by the Croatians)

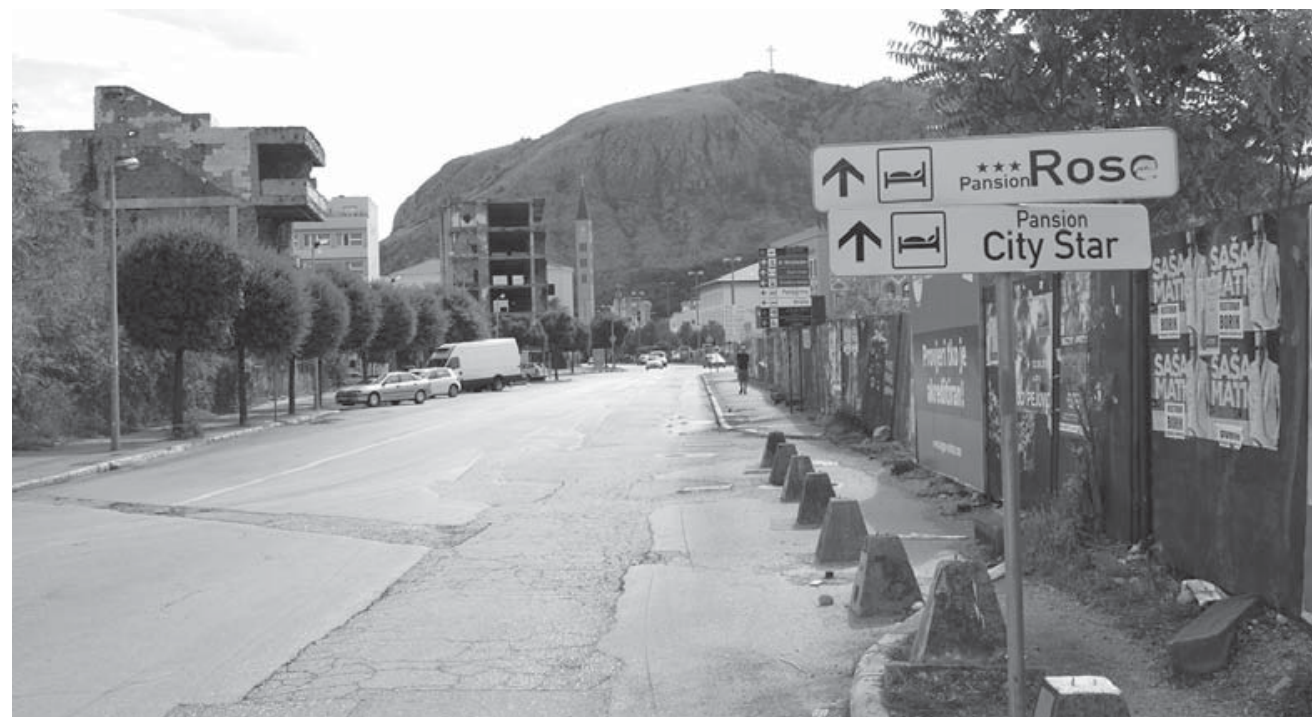

Source: Author

Picture 7: The reinforced concrete walls of the Franciscan Church seem a bit crude, but all the more compelling (The building and its surroundings are a centre for the Croatian community beyond the religious occasions)

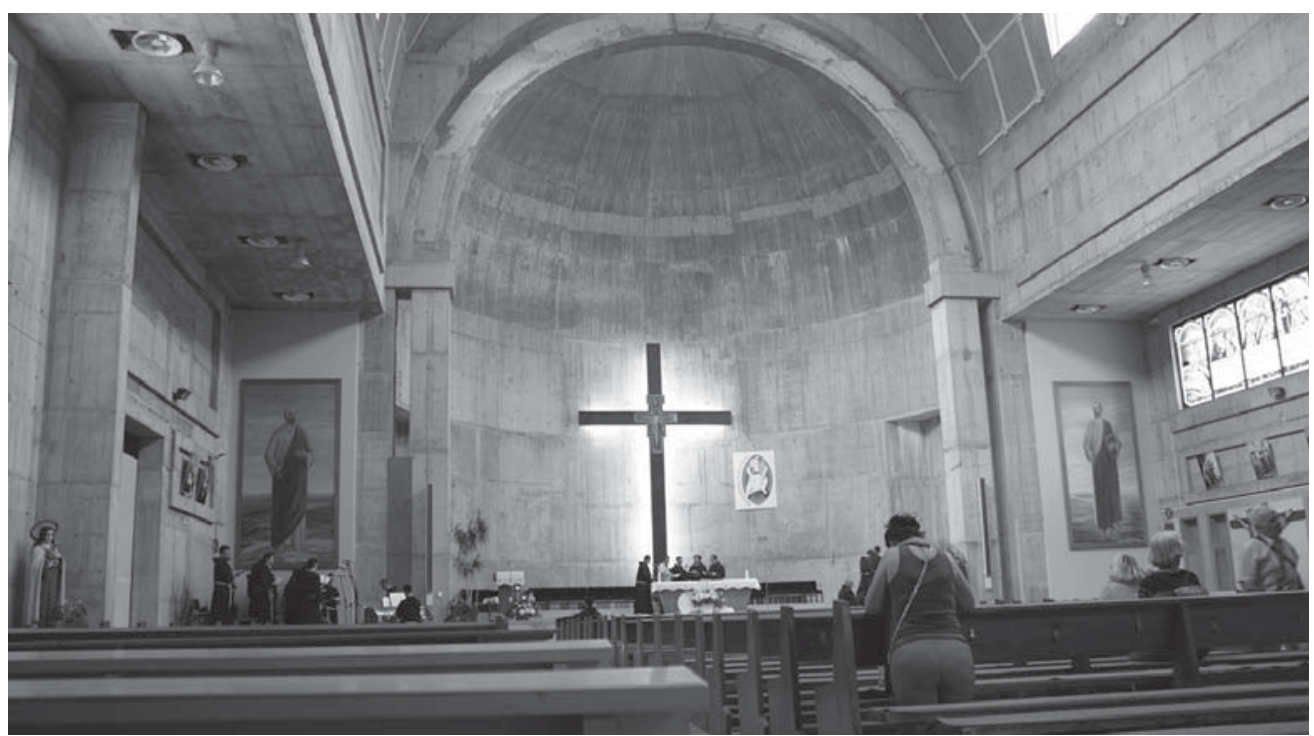

Source: Author 
Continuing on the Bulvar, the city hall of Mostar, and the nicely renovated block of the secondary school come into sight, the latter built during the Monarchy partly with NeoMoorish architectural elements. But the widening square is also edged by unrenovated, ruined buildings. This is the Spanish Square, built to commemorate the Spanish SFOR soldiers. They built the suspension bridge linking the two banks of Neretva River, functioning as temporary crossing until the Old Bridge was restored. From here, a vista - named after Nikola Subić Zrinski, a late Croatian "ban" - fringed by an imposing line of plane trees and countless villas, leads to the "rondo", where the Croatian Cultural Centre (Hrvatski dom hercega Stjepana Kosače) stands. The building houses, besides the county branch of the National Library, a concert and event venue, and the headquarters of the Herzeg-Bosnian radio. The names of the public spaces leading here show that we are in the districts inhabited by Croats. The streets are named almost exclusively after the $10-11^{\text {th }}$ century rulers of then still independent Croatia or after the then still Catholic Bosnian rulers: visitors may come across the names of Mihajlo Višević, Knjiez Branimir and Kralj Tvrtko, among others.

The religious centre of the Serbs - the Orthodox church (Congregational Church of the Holy Trinity) - was built on the hillside in the eastern part of the city in 1863-1873, is towering high enough to be visible from many places within the city (Picture 8).

Picture 8: The Orthodox Cathedral, under renovation, is barely visible among the minarets (Behind it, the rectory is really rather guessed than seen, symbolizing the drastic decrease in the number of Serbs in the town)

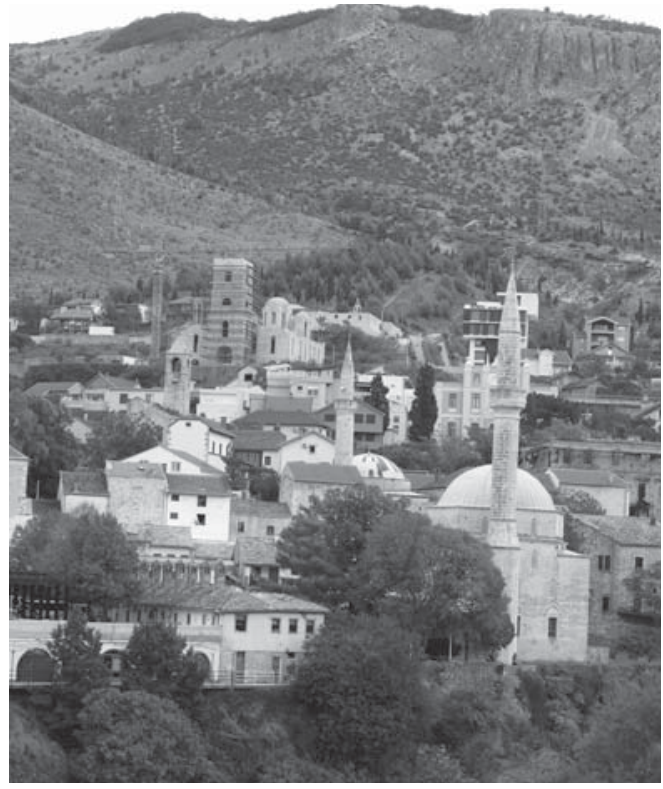

Source: Author The renovation of the latter began in 2010, but is still delayed, though it is clear that the community wants to restore it to its original splendour. Presumably, the reduction of the Serb community plays a role in the fact that this neighbourhood is not a vital part of the city, but rather a periphery, even though it is easily visible from many parts of the city.

The east-west oriented roads leading to the three bridges that arch over the Neretva have kept the names they were given after the partisan units that claimed victory in World War II not only over the German invaders, but also against their own internal opposition ("Street of the Mostar Battalion", "Street of the $10^{\text {th }}$ Herzegovinian Brigade"). Similarly, the name of the street that constitutes the main transport artery of the Bosnian Muslim district, given after the great partisan leader, Josip Broz Tito, also remains the same. Presumably, the Bosnians regard this era more as positive because of the recognition of southern Slavic speaking Muslims as a separate entity. 
The former historical district, having retained most of its economic functions, is evidently still an urban space that belongs to the Bosnians (Picture 9). Tourism has made it possible for former activities - retail, catering, and to some extent even handicraft businesses - to live on and cater to the great numbers of tourists. However, the small shops are selling souvenirs, rather than household goods; instead of the large leather tanneries, "jewel smiths" are offering their merchandise; and the caravanserais have been replaced by restaurants and hotels, serving several thousand tourists. The activities aimed at serving tourists define the wider surroundings as well. The mosques, still significant in number, keep functioning as community spaces, while the parks and squares created between the blocks of houses built in later years serve as graveyards for the victims of the war of the 1990s, and also as memorials.

This parallelism has other visible forms in everyday life as well (Vetters 2007). Besides the above-demonstrated symbolism of the use of urban spaces, the segregation of the two communities of the city is also shown by the fact that educational institutions (elementary and secondary schools) are run parallel by the two communities. The division is also shown by the fact that Džemal Bijedić University, named after the prime minister of Yugoslavia who died in 1977, the same year as the institution's founding, has also split and operates in parallel. The Croatian university, named University Mostar, broke off from that institution and was founded in 1992, during the war. Naturally, both institutions are located in their "respective" districts.

Picture 9: The inner courtyard of the Koski Mehmet Pasha Mosque, a significant centre of the Muslim community

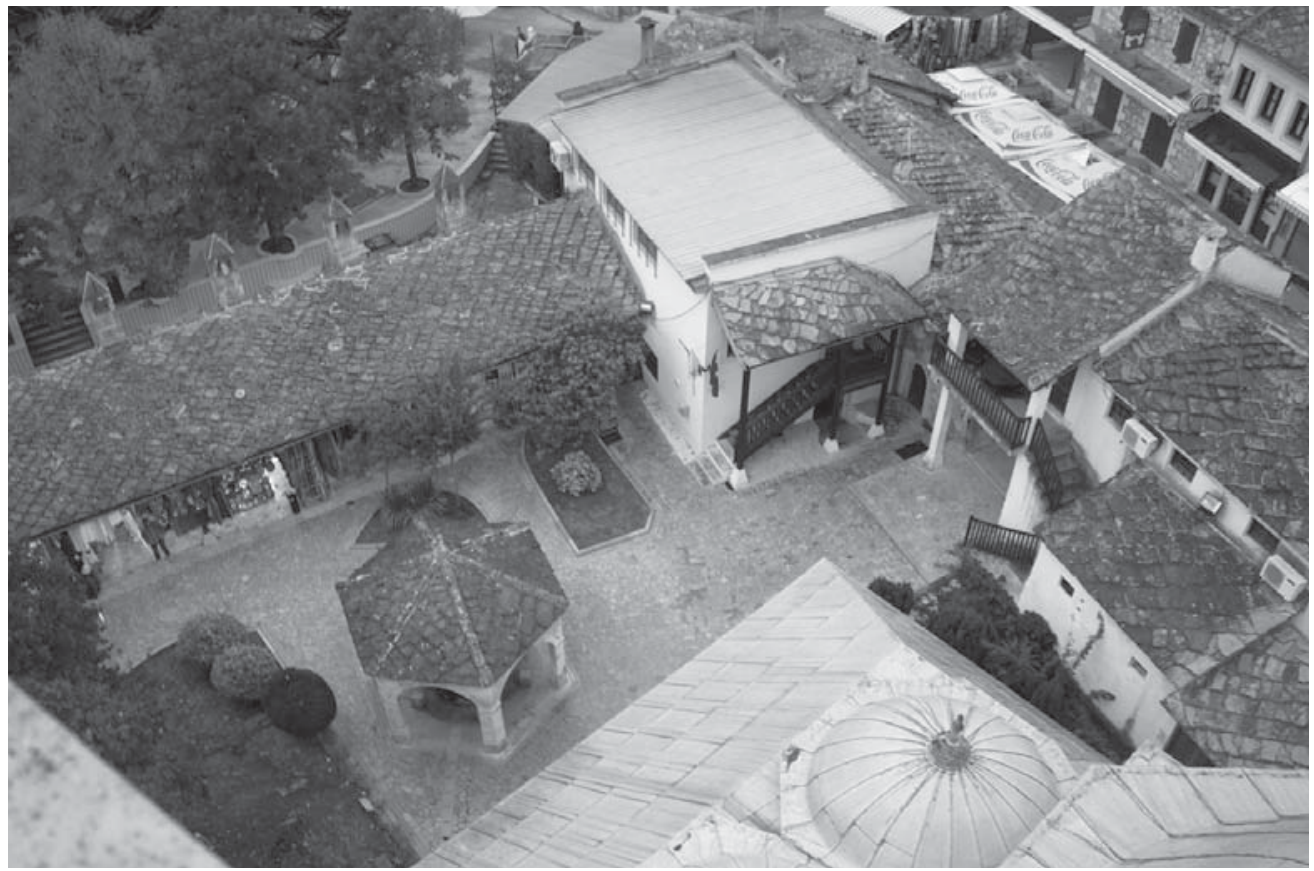

Source: Author 
The examination of the ethnic space structure of Bosnia and Herzegovina - lying at the juncture of various world religions and cultures - directs our attention to several social dimensions. The war that took place between 1992 and 1995 - as we have seen - has had multiple consequences, which are hard to understand without understanding the historical background. In Tito's Yugoslavia, the heterogeneous ethnic composition of the country was written into the Constitution. Bosnia and Herzegovina received a special status within a country that was a federation of nation states: it was defined as a multi-nationality republic, based on its ethnically mixed population. At the same time in Yugoslavia, rather than ethnicity being in the foreground, emphasis was placed on similarities (language), based on the principle of proletarian internationalism. Another important factor was the Third Way Yugoslav politics, which placed the country's southern Slavic speaking Muslim population in the foreground, such that at the time of the change in political regime, the Bosnians considered Bosnia and Herzegovina as their own country with a major Serbian and Croatian minority. This fact brought to the surface frustrations caused by ethnic differences rooted in historical traditions (Melčić 2007). Based on our observations, these oppositions and conflicts are visible on the micro level of society, through the establishment of identities and space usage. These open up new questions. And altogether they question and override

Picture 10: The symbol of the country is a tribute to the victims of war (In memory of all members of the Republic of Bosnia and Herzegovina army, who sacrificed their lives in defense of the country and of the city of Mostar during the 1992-1995 war)

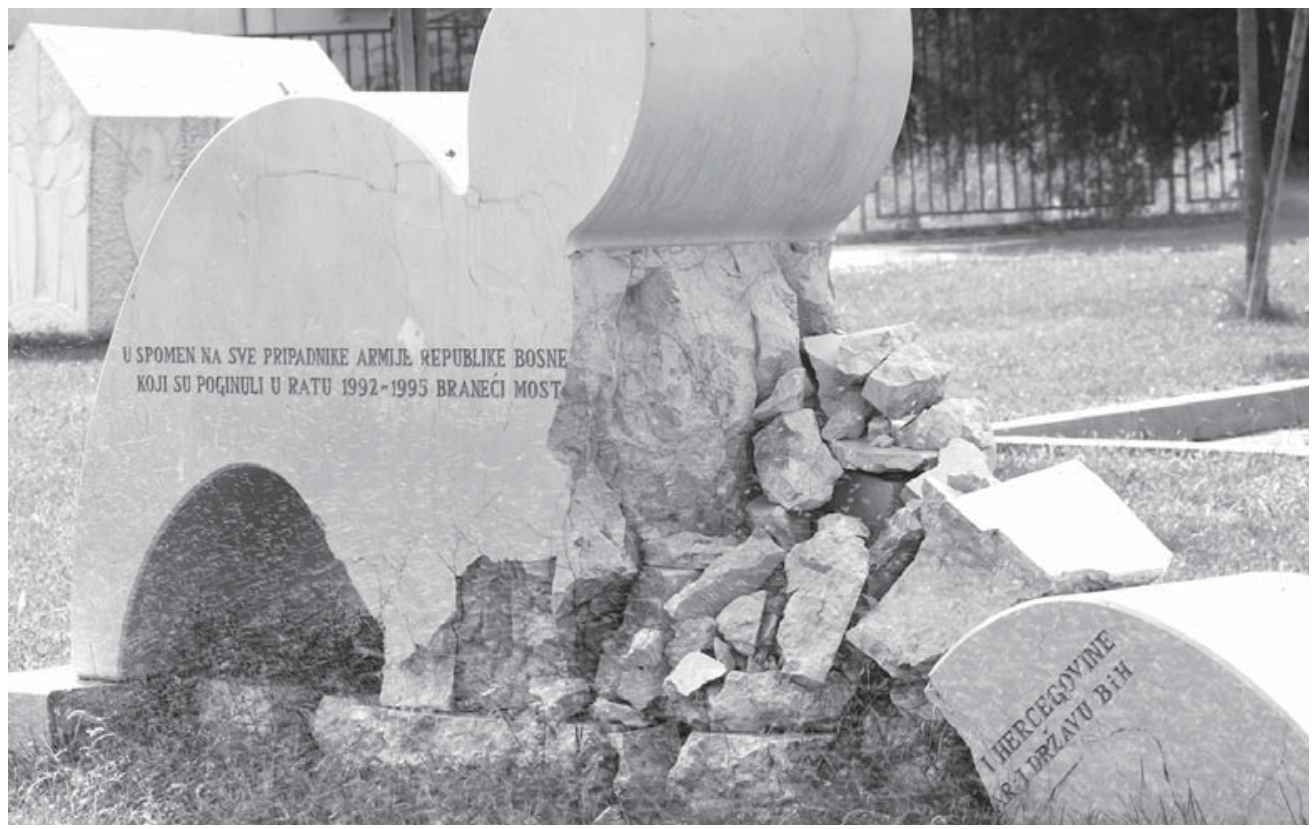

Source: Author 
the (Western European) visions of a peaceful co-existence in a wider In-Between European sense, and the belief in the multicultural nature of the globalized world. Based on the abovementioned, we are convinced that it is worth carrying on micro-level research of this type (at the same time broadening the examination of segregation to workplaces, public spaces and other dimensions beyond dwelling places) accompanied by comparative researches targeting other multi-ethnic or multi-confessional towns of the region, and thereby identify the types of coexistence and generalize future results.

\section{References}

ANDERSON, Benedict. 1983. Imagined Communities - Reflections on the Origin and Spread of Nationalism. New York: Verso.

AMZI-ERDOĞDULAR, Leyla. 2013. "Afterlife of Empire: Muslim-Ottoman Relations in Habsburg Bosnia Herzegovina, 1878-1914.” Doctoral dissertation. Columbia University. Retrieved September 19, 2017 (https://academiccommons.columbia.edu/catalog/ac:174849).

ASBÓTH, János. 1890. An Official Tour Through Bosnia and Herzegovina with an Account of the History, Antiquities, Agrarian Conditions, Religion, Ethnology; Folk Lore, and Social Life of the People. London: Sonnenschein.

BALIĆ, Smail. 1991. "Das Bosniakentum als Nationales Bekenntnis.” Österreichische Osthefte 33(3-4): 345-357.

BALIĆ, Smail. 1996. “Die Bosniaken.” Pp 63-75 in Der Balkan in Europa, edited by Eggert HARDTEN, Andre STANISJAVLJEVIC and Dimitris TSAKIRIS. Berlin: Peter LANG Verlag.

BERKI, Márton. 2014. "Return to the Road of Capitalism: Recapitulating the Post-Socialist Urban Transition." Hungarian Geographical Bulletin 63(3): 319-334.

BÜSCHENFELD, Herbert. 2000. "Kriegsfolgen und Wiederaufbau in Bosnien-Herzegowina." Geographische Rundschau 52(2): 55-62.

DEMETER, Gábor. 2012, 2014, 2016. A Balkán és az Oszmán Birodalom I-III. - Társadalmi és gazdasági átalakulások a 18. század végétöl a 20. század közepéig [The Balkans and the Ottoman Empire I-III. - Social and economic transformations from the end of the 18th century to the mid 20th century]. Budapest: MTA Bölcsészettudományi Kutatóközpont Történettudomány Intézet.

DŽAJA, Srečko-Matko. 1984. Konfessionalität und Nationalität Bosniens und der Herzegowina. Munich: Oldenburg Verlag.

DŽAJA, Srečko-Matko. 1993. "Bosnien und Herzegowina." Pp 149-175 in Der ruhelose Balkan - die Konfliktregionen Südosteuropas, edited by Michael WEITHMANN. Munich: DTV.

FÓNAGY, Zoltán. 2014. "Bosznia-Hercegovina integrációja az okkupáció után [Integration of Bosnia and Herzegovina after the Occupation (1878)]." Történelmi Szemle 56(1): 27-60.

GENTZIK, Cristina. 2008. "The Bridge of Mostar - A Controversial Symbol of Identity." Euro-Facta 1: 315-324.

GRODACH, Carl. 2002. "Reconstituting Identity and History in Post-war Mostar, Bosnia-Herzegovina." City - Analysis Of Urban Trends, Culture, Theory, Policy, Action 6(1): 61-82.

HAPPEL, Jörn and Christophe V. WERDT. 2010. Osteuropa kartiert-Mapping Eastern Europe. Vienna: LiT Verlag.

HALILOVIĆ, S. 1999. “Das Bosnische [Sprache].” Pp 413-428 in Handbuch der Südosteuropa Linguistik (Slawische Studienbücher 10.), edited by Uwe HINRICHS. Wiesbaden: Hassarowitz Verlag. 
HOBSBAWM, Eric. 1991. Nationen und Nationalismus, Mythos und Realität seit 1780. Frankfurt am Main: Campus.

IBRAHIMI, Nexhat. 2009. "Islam's First Contacts with the Balkan Nations." Zëri Islam. Retrieved September 19, 2017 (http://www.zeriislam.com/artikulli.php?id=927).

JORDAN, Peter. 1995. Ethnische Struktur Südosteuropas um 1992. Vienna: Österreichisches Ost- und Südosteuropa-Institut.

JUHÁSZ József. 2005. “Jugoszlávia 1945-2000.” [Yugoslavia 1945-2000]. Pp. 434-445 in 20. századi egyetemes történet, I. kötet - Európa $\left[20^{\text {th }}\right.$ century universal history, Volume I - Europe], edited by István NÉMETH. Budapest: Osiris Kiadó.

KATONA Péter. 2010. "Szeparatizmus, dezintegráció és regionalizmus: Jugoszlávia felbomlásának geopolitikai vonatkozásai." [Separatism, disintegration and regionalism: geopolitical aspects of the break-up of Yugoslavia]. Pp. 181-222 in Kompországok-ahol a part szakad... Szemelvények Köztes-Európa integrációs törekvéseiböl (1990-2008) [Ferry-countries - where the shore breaks ... Excerpts from the aspirations of the inter-Europe integration (1990-2008)], edited by Gábor DEMETER and Zsolt RADICS. Debrecen: Didact kiadó.

KOCSIS, Károly and Patrik TÁTRAI, eds. 2015. A Kárpát-Pannon-térség változó etnikai arculata [Changing Ethnic Patterns of the Carpatho-Pannonian Area]. Budapest: MTA CSFK Földrajztudományi Intézet.

KÖSZEGI, Margit. 2015. “Territorial Aspect of Population Decline in Bulgaria.” Pp. 381-395 in Shared Pasts in Central and Southeast Europe 17th-21st Centuries: Hungarian and Bulgarian Approaches, edited by Gábor DEMETER and Penka PEYKOVSKA. Sofia-Budapest: Institute of History and Bulgarian Academy of Sciences.

KOSTOF, Spiro. 1992. The City Assembled: Elements of Urban Form through History. Boston: Little Brown.

LOPASIĆ, Alexander. 2001. "Islam in the Balkans: The Bosnian Case." Pp. 141-157 in Religious Quest and National Identity in the Balkan, edited by Celia HAWKESWORTH, Muriel HEPPEL and Harry NORRIS. London: Palgrave Macmillan.

LOZA, Tihomir, KRAUTHAMER, Ky, GARDNER, Andrew, DRUKER, Jeremy et al. 2004. "The Bridge over the River Neretva.” Transitions Online 07(27). Retrieved September 19, 2017 (http://www.tol.org/ client/article/12472-the-bridge-over-the-river-neretva.html).

LUCHETTA, Andrea. 2009. Mostar and the Loss of Its (Partial) Uniquess: A History, 1990-2009. Doctoral dissertation. Geneva: Graduate Institute of International and Development Studies.

MALCOLM, Noel. 1994. Bosnia: A Short History. London: Macmillan.

MELČIĆ, Dunja, ed. 2007. Der Jugoslawien-Krieg. Handbuch zu Vorgeschichte, Verlauf und Konsequenzen. Wiesbaden: VS Verlag für Sozialwissenschaften.

MOLNÁR, Antal. 2000. “A ferencesek Boszniában a középkorban és a török uralom első időszakában (13-17. század)." [The Franciscans in Bosnia during the Middle Ages and the first period of Turkish rule (13-17th centuries)]. Limes: Tudományos Szemle 12(2-3): 39-64.

MORAVANSZKY, Ákos. 1998. Aesthetic Invention and Social Imagination in Central European Architecture, 1867-1918. Cambridge, MA: MIT Press.

NIEMANN, Patrick and Paul REUBER. 2015. "Mostar als Experimentierfeld europäischer EntwicklungsInterventionen? Probleme und Schwierigkeiten in einer post-konfliktiven Region.” Europa regional 21(3): 122-137.

OKEY, Robin. 2007. Taming Balkan Nationalism: The Habsburg “Civilizing Mission” in Bosnia, 1878-1914. Oxford: Oxford University Press.

PÁNDI, Lajos. 1997. Köztes-Európa 1763-1993 - Térképgyüjtemény [In-between Europe 1763-1993 Map Collection]. Budapest: Osiris/Századvég. 
PIERCE, Joseph and Mary LAWHON. 2015. "Walking as Method: Toward Methodological Forthrightness and Comparability in Urban Geographical Research." The Professional Geographer 67(4): 655-662.

RING, Éva. 2004. Államnemzet és kulturnemzet válaszútján [On the crossroads of the State-nation and Culture-nation]. Budapest: ELTE Eötvös Kiadó.

SIMMEL, Georg. 1992 [1903]. "Soziologie des Raumes.” Schriften zur Soziologie Frankfurt am Main.

STEINDORFF, Ludwig. 1997. "Von der Konfession zur Nation. Die Muslime in Bosnien-Herzegowina." Südosteuropa Mitteilungen 37(4): 277-290.

STEINDORFF, Ludwig. 1998. "Identität, Ethnizität und Nationalität in Südosteuropa - Einleitung." Pp. 11-17 in Ethnizität, Identität und Nationalität in Südosteuropa. Beiträge zu einem Präsentationstag der Südosteuropa-Forschung an der Universität Münster am 27. 11. 1998, edited by Cay LIENAU and Ludwig STEINDORFF. Munich: Südosteuropa-Gesellschaft, 2000.

STEINDORFF, Ludwig. 2001. "Bosnien Herzegowina: geschichte der äußeren und inneren Grenzen." Pp. 137-156 in Raumstrukturen und Grenzen, edited by Cay LIENAU. Munich: Südosteuropa Gesellschaft.

SUGAR, Peter F. 1964. Industrialization of Bosnia-Hercegovina: 1878-1918. Seattle: University of Washington Press.

SÝKORA, Luděk. 2009. "Post-Socialist Cities.” Pp. 387-395 in International Encyclopedia of Human Geography (Volume 8), edited by Rob KITCHIN and Nigel THRIFT. Oxford: Elsevier.

SZÜCS, Jenö. 1985. Les trois Europes. Paris: 1'Harmattan.

VETTERS, Larissa. 2007. "The Power of Administrative Categories: Emerging Notions of Citizenship in the Divided City of Mostar." Ethnopolitics 6(2): 187-209.

VOSS, Christian. 2006. "Die slawischsprachige Balkanmuslime: kulturelle Identitäten und Sprachideologien.” Südosteuropa Mitteilungen 46(2): 57-69.

YARWOOD, John. 1999. Rebuilding Mostar: Urban Reconstruction in a War Zone. Liverpool: Liverpool University Press.

\section{Author}

Zsolt Bottlik is a geographer and Associate Professor at the Institute of Geography and Earth sciences at Eötvös Loránd University in Budapest, Hungary.

Contact: agria@gmx.net 